\title{
Transformasi Digital di Industri Perbankan Indonesia: Impak pada Stress Kerja Karyawan
}

\author{
Shinta Winasis \\ Program Doktoral Universitas Mercubuana Jakarta \\ shintawinasis@gmail.com \\ Setyo Riyanto \\ Program Doktoral Universitas Mercubuana Jakarta \\ setyoriyanto@gmail.com
}

\begin{abstract}
Abstrak:
Digital transformation is currently become a very important agenda in the Indonesian Banking Industry. The need for transformation has became top priority for companies, to be more agile in rapidly changing market. Changes that occur due to transformation are disruptive and very dynamic. Working procedures and conditions that have been running conventionally for decades must be radically changed to ensure companies can adapt to a highly competitive landscape. Companies must implement an integrated digital transformation strategy to improve performance and hence increase company's long term business opportunity in a sustainable manner. In this phase, companies need commitment, engagement, and also support from employees. However changes will directly affect employee' psychological conditions, and if not handled properly will generate their resistance of change and at the end will give negative influences of overall process. This research will present dan discuss a survey result conducted concerning the conditions of work stress experienced by employees in a private banks that have made radical technology-based changes for 1 year. The result showed that there were indications of work stress and as an implication, further research was proposed on the issues discussed

[Transformasi digital saat ini merupakan salah satu agenda penting dalam industri Perbankan Indonesia. Kebutuhan akan transformasi menjadi prioritas utama bagi perusahaan, agar lebih agile dalam pasar yang berubah dengan cepat. Perubahan yang terjadi akibat transformasi bersifat mendasar, disruptif \& sangat dinamis. Prosedur dan kondisi kerja yang telah berjalan secara konvensional selama beberapa dekade harus diubah secara radikal untuk memastikan perusahaan dapat beradaptasi dalam lanskap yang sangat kompetitif. Perusahaan harus menerapkan strategi transformasi digital terintegrasi untuk meningkatkan kinerja perusahaan dan karenanya meningkatkan peluang bisnis jangka panjang perusahaan secara berkelanjutan. Pada fase ini perusahaan membutuhkan komitmen dan engagement/keterikatan dan dukungan dari karyawannya. Namun perubahan akan secara langsung mempengaruhi kondisi psikologis berupa munculnya indikasi stress kerja karyawan, dan jika tidak ditangani dengan baik akan menghasilkan resistensi dan pengaruh negatif pada perubahan itu sendiri. Pada penelitian akan dipresentasikan hasil survei mengenai kondisi stress kerja yang dialami oleh karyawan di bank swasta yang telah melakukan perubahan radikal berbasis teknologi selama 1 tahun. Hasil penelitian menunjukkan bahwa terdapat indikasi adanya stress kerja dan sebagai implikasinya diusulkan penelitian lebih lanjut tentang masalah yang dibahas.]
\end{abstract}

Kata Kunci: Transformasi digital, Industri Perbankan, Stress Kerja, Engagement 


\section{PENDAHULUAN}

Transformasi digital saat ini sedang berlangsung dengan kecepatan tinggi dan berdampak pada hampir semua area kehidupan. Transformasi digital merupakan konsekuensi dari era disrupsi atau lebih dikenal sebagai Era Industri 4.0, sehingga terjadi perubahan model bisnis, merombak ekosistem bisnis yang ada menjadi ekosistem baru yang lebih inovatif, kompleks dan dinamik. ${ }^{1}$ Pada bisnis perbankan yang selama bertahun-tahun berjalan konvensional, transformasi digital berarti melakukan perombakan signifikan dalam prosedur, cara kerja, struktur organisasi dan model bisnis, agar dapat lebih fleksibel menghadapi perubahan. ${ }^{2}$ Perubahan radikal ini dilakukan untuk mempertahankan eksistensi bisnis, dan berjalan seiring dengan perubahan preferensi dan cara bertransaksi nasabah dan masuknya pesaing non bank. Proses transformasi digital tidak hanya memberikan kesempatan untuk melakukan perombakan total terhadap proses kerja dan sistem yang telah berjalan sejauh ini, sehingga menjadikan proses kerja lebih efisien dan efektif, tetapi juga memberikan kesempatan bagi pelanggan untuk meningkatkan pengalaman bertransaksi mereka selama proses berlangsung, ${ }^{3}$ Proses perubahan yang terjadi perlu didukung oleh strategi transformasi yang tepat, agar dapat memberikan daya saing dan nilai lebih terhadap bisnis perusahaan. ${ }^{4}$ Transformasi digital memiliki dua sisi. Dampak yang kuat akan terasa sebagai akibat dari perubahan cara pelanggan melakukan transaksi. Saluran distribusi seperti internet banking, mobile banking, chatbot, kecerdasan buatan dan aplikasi media sosial semakin banyak digunakan. Jika strategi digital diterapkan dengan tepat, sesuai dengan permintaan dan kebutuhan pelanggan, diharapkan akan ada peningkatan loyalitas pelanggan.

Di sisi lain, teknologi digital akan mengurangi dan mengancam keberadaan perbankan tradisional yang mengkedepankan transaksi manual, yang berarti akan ada pemotongan dalam prosedur kerja, dan lebih lanjut berakibat pada pengurangan tenaga kerja. ${ }^{5}$ Transformasi harus dilakukan dalam waktu yang cepat karena dalam era disrupsi, waktu adalah variabel esensial yang menjadi penentu keberlangsungan/sustainibilitas perusahaan. ${ }^{6}$

Transformasi digital dalam industri perbankan Indonesia dimulai terlambat dibandingkan dengan negara-negara Asia lainnya seperti Malaysia, Singapura, dan Korea Selatan. Hal ini disebabkan, antara lain, kondisi geografis Indonesia yang merupakan negara kepulauan, di mana literasi digital tidak homogen, dan pelanggan layanan perbankan masih memiliki preferensi untuk melakukan transaksi fisik di cabang perbankan konvensional. Pada awal 1980an, mesin ATM diperkenalkan dan dengan cepat menjadi solusi alternatif untuk melakukan transaksi perbankan. Pada tahun 1990, ketika kebutuhan untuk transaksi antar bank meningkat, beberapa bank mulai berinvestasi dalam teknologi, menganggapnya sebagai solusi untuk mengatasi ancaman yang muncul dari kegiatan bisnis bank asing di Indonesia.

\footnotetext{
1 Berman, S. J., Digital transformation: opportunities to create new business models. Journal of Strategy \& Leadership, 40(2), 2012, 17.

2 Jahn, C. G., \& Kruse, P. 'Partly Reversed Measures': Critically Assessing the Management of Resistance Within Radical Changes-Accompanying Banking Employees on Their Identity, Journey During Digital Transformation, Lund University Lib, 2019, 62.

3 Omarini, Anna. The digital transformation in banking and the role of FinTechs in the new financial intermediation scenario. International Journal of Finance, Economics and Trade, 2017, 3.

${ }^{4}$ Liu, D., Chen, S., \& Chou, T. Resource fit in digital transformation. Journal of Management Decision, 49(10), 2011, 1729.

5 Nguyen T, Phuong Dang T, Digital Banking in Vietnam Current Situation and Recommendations, International Journal of Innovation and Research in Educational Sciences Volume 5, Issue 4, $2018,418$.

6 Winasis S, et al, Digital Transformation in Indonesian Banking Industry: Impact on Employee Engagement, International Journal of Innovation, Creativity and Change, Volume 12 Issue 4, 2020, 529. 
Bank kemudian mulai meningkatkan sistem pembayaran internal, memulai era baru transaksi online. Pada tahun 2000-an, perkembangan teknologi perbankan menjadi suatu keharusan, karena bank-bank yang telah selamat dari krisis ekonomi Indonesia tahun 1998, harus bersaing dengan bank asing untuk memperebutkan pasar pelanggan yang pada waktu itu, telah kehilangan kepercayaan mereka pada bank lokal. Pada dekade berikutnya, 2010-an dan seterusnya, keunggulan perbankan digital telah menjadi salah satu poin penting yang membuat bank bertahan dalam krisis ekonomi kedua. Beberapa bank mulai menggunakan berbagai platform media sosial untuk menyampaikan, memperkenalkan dan mensosialisasikan berbagai fitur produk, membuka saluran layanan keluhan pelanggan, dan mendorong komunikasi dua arah yang interaktif, sehingga pelanggan merasa lebih terhubung dan dihormati. Strategi-strategi ini menghilangkan paradigma lama bahwa layanan perbankan hanya dapat diakses melalui cabang konvensional. ${ }^{7}$

Tuntutan digitalisasi perbankan juga diperkuat oleh pergeseran kepemilikan bisnis, yang saat ini didominasi oleh generasi milenial, yang lebih menyukai kenyamanan transaksi online melalui platform digital. Jumlah pengguna internet di Indonesia, mencapai 54,68\% dari total populasi 262 Juta penduduk, ${ }^{8}$ dimana $87 \%$ nya merupakan pengguna aktif aplikasi chat dan $74.84 \%$ merupakan pengguna aktif aplikasi media sosial. Data ini menggambarkan satu ceruk yang menjanjikan bagi bank untuk mengubah strategi pemasaran dari konvensional menjadi digital, sehingga mendorong peningkatan literasi layanan perbankan digital. Urgensi proses transformasi perbankan juga didorong oleh bermunculannya pesaing baru, yaitu perusahaan penyedia jasa keuangan non perbankan, atau biasa disebut fintech. Bisnis fintech mulai menggerus layanan perbankan karena berbagai kemudahan yang ditawarkan tanpa birokrasi yang rumit. Data dari Capgemini, ${ }^{9}$ memberikan gambaran bahwa secara global lebih dari $63 \%$ pelanggan perbankan juga menggunakan jasa layanan perusahaan fintech. Di Indonesia sendiri bisnis fintech menjadi booming di tahun 2018 sampai saat ini dengan kemudahan pembayaran digital lintas platform. Bahkan beberapa perusahan start up seperti Gojek, mulai melirik bisnis ini karena prospek dan pangsa pasar yang terus berkembang. Maraknya penggunaan aplikasi pembayaran dan uang digital, mengakibatkan penurunan permintaan uang kertas PT Peruri sebesar $19 \%$ pada tahun $2018^{10}$ dan penurunan pertumbuhan pengguna kartu kredit ${ }^{11}$

Sisi lain dari transformasi digital adalah tidak homogennya transformasi ini terjadi. Untuk pelaku industri perbankan skala besar, yaitu bank buku 4, investasi untuk transformasi merupakan issue yang tidak sulit dilakukan. Bahkan proses digitalisasi sudah dijalankan secara bertahap dalam 10 tahun kebelakang. Namun untuk bank buku 1-3, proses transformasi memerlukan pertimbangan yang matang bukan hanya karena nilai investasi yang tinggi, namun risiko sistemuk bagi perusahaan, jika terdapat kegagalan proses, akan

\footnotetext{
7 Winasis S, et al, Digital Transformation in Indonesian Banking Industry: Impact on Employee Engagement, International Journal of Innovation, Creativity and Change, Volume 12 Issue 4, 2020, 530.

8 Kominfo, Press Release No 53/HMKOMINFO/02/2018, available at https://kominfo.go.id/index.php/content/detail/12640/siaran-pers-no-53hmkominfo022018tentang-jumlah-pengguna-internet-2017-meningkat-kominfo-terus-lakukan-percepatanpembangunan-broadband/0/siaran pers, 2018.

${ }^{9}$ CapGemini, World Retail Banking Report. Available at www.capgemini.com, 2016.

${ }^{10}$ Richard M, Kala Bisnis Percetakan Uang Peruri Digerogoti Uang Digital, Artikel Bisnis.com, 12 Nov 2019 Edition, 2019.

${ }^{11}$ Sitanggang L, Bankir Akui Bisnis Kartu Kredit terdisrupsi Uang Elektronik, News Data Financial Tool, Artikel Kontan 20 Juni 2019 Edition, 2019.
}

Iqtishadia: Jurnal Ekonomi dan Perbankan Syariah 
menimbulkan kerugian potensial bagi bank. Untuk bank perkreditan rakyat baik berbasis umum atau berbasis Syariah, perubahan digitalisasi belum dilakukan secara masif dan seragam, dengan mempertimbangkan bahwa tipe customer yang lebih banyak ada di kategori retail dengan cara bertransaksi yang masih konvensional, dianggap belum terlalu membutuhkan aplikasi digital terintegrasi untuk membantu proses transaksinya. Namun kebijakan ini dinilai menjadi salah satu sebab beberapa BPR mengalami kesulitan untuk bersaing dalam industri, dan akhirnya tutup operasi.

Langkah-langkah strategi digital tidak hanya untuk menambahkan produk dalam berbagai platform digital, atau menambahkan mesin-mesin canggih, tetapi harus mencakup strategi komprehensif yang mencakup proses, talent \& model bisnis. Banyak organisasi telah gagal dalam melakukan proses transformasi, karena antara lain, mereka lebih fokus pada strategi kondisi operasional tertentu, hanya dilakukan dalam fragmen waktu tertentu dan tidak mempertimbangkan dampak di masa depan. Perusahaan yang memiliki kematangan digital akan menunjukkan kemampuan mereka untuk mengubah bisnis mereka untuk mengikuti perkembangan era disrupsi, meningkatkan efisiensi, meningkatkan laba perusahaan, dan terutama memberikan nilai tambah kepada pelanggan melalui pengalaman bertransaksi yang pada akhirnya akan loyalitas pelanggan. ${ }^{12}$ Dalam dunia bisnis perbankan Indonesia, keberhasilan jalannya strategi perubahan akan mempertahankan keberlangsungan perusahaan di masa depan.

Makalah ini akan membahas dampak transformasi digital pada stress kerja karyawan. Survei dilakukan di antara 41 staf cabang bank swasta yang telah menjalankan program transformasi digital selama 2 tahun. Hasil survey yang dibahas dalam makalah ini dapat diperluas untuk penelitian lebih lanjut.

\section{METODE PENELITIAN}

Penelitian ini akan menggunakan pendekatan kuantitatif melalui penyebaran kuisioner survey. Survey dilakukan pada bulan Februari 2019 terhadap 41 karyawan salah satu cabang bank swasta yang berlokasi di Kawasan bisnis perdagangan grosir tektil Tanah Abang. Cabang ini memiliki 110 karyawan dan merupakan 1 dari 8 cabang pilot project proses transformasi difital perusahaan selama 1 tahun. Responden merupakan karyawan yang telah bekerja minimal selama 2 tahun sehingga dapat memberikan masukan terhadap kondisi kerja era sebelum dan sesudan transformasi. Proses transformasi yang dilakukan perusahaan merupakan perubahan radikal, karena terdiri dari perubahan prosedur kerja, alih teknologi, penambahan dan enhancement mesin, perombakan struktur organisasi dan budaya perusahaan.

\section{HASIL DAN PEMBAHASAN}

Hasil survey pada penelitian ini dapat disarikan sebagai berikut :

Tabel 1

Hasil Survey terhadap Karyawan Perbankan

\begin{tabular}{|c|c|c|}
\hline Pernyataan & \% Y & $\mathbf{\% ~ N}$ \\
\hline Saya yakin kemampuan saya & 53.66 & 46.34 \\
\hline
\end{tabular}

12 Winasis S, et al, Digital Transformation in Indonesian Banking Industry: Impact on Employee Engagement, International Journal of Innovation, Creativity and Change, Volume 12 Issue 4 2020, 531. 


\begin{tabular}{|l|c|c|}
\hline $\begin{array}{l}\text { akan membuat saya tidak } \\
\text { tergantikan }\end{array}$ & & \\
\hline $\begin{array}{l}\text { Saya sangat tertarik mengikuti } \\
\text { perkembangan perubahan }\end{array}$ & 87.80 & 12.20 \\
\hline $\begin{array}{l}\text { Saya mau belajar untuk } \\
\text { menguasai perubahan cara } \\
\text { kerja yang terjadi }\end{array}$ & 97.56 & 2.44 \\
\hline $\begin{array}{l}\text { Saya yakin saya memilki } \\
\text { kemampuan untuk mengikuti } \\
\text { perubahan }\end{array}$ & 60.98 & 39.02 \\
\hline $\begin{array}{l}\text { Saya pasti bisa mengikuti } \\
\text { perubahan dalam kondisi } \\
\text { apapun }\end{array}$ & 75.61 & 24.39 \\
\hline $\begin{array}{l}\text { Saya khawatir pekerjaan saya } \\
\text { akan tergantikan oleh mesin }\end{array}$ & 65.85 & 34.15 \\
\hline $\begin{array}{l}\text { Project transformasi digital ini } \\
\text { pasti akan menjadikan } \\
\text { perusahaan saya lebih unggul }\end{array}$ & 100.00 & 0.00 \\
\hline $\begin{array}{l}\text { Saya merasa tidak nyaman } \\
\text { dengan adanya banyak } \\
\text { perubahan }\end{array}$ & 41.46 & 58.54 \\
\hline $\begin{array}{l}\text { Saya merasa tuntutan } \\
\text { pekerjaan saat ini membuat } \\
\text { saya cemas }\end{array}$ & 43.90 & 56.10 \\
\hline $\begin{array}{l}\text { Saya mempertimbangkan untuk } \\
\text { resign dari perusahaan saya ini }\end{array}$ & 19.51 & 80.49 \\
\hline $\begin{array}{l}\text { Saya merasa memiliki masa } \\
\text { depan yang baik jika bekerja } \\
\text { terus di perusahaan ini }\end{array}$ & 68.29 \\
\hline
\end{tabular}

Berdasarkan hasil survey, terlihat bahwa sebagian besar staf $(87,80 \%)$ antusias dengan perubahan yang terjadi, bahkan hampir semua staf (97,56\%) mengaku memiliki keinginan untuk belajar menguasai perubahan pekerjaan dan alih teknologi yang terjadi. Namun hampir setengah dari responden (46\%) merasa khawatir akan adanya pemutusan hubungan kerja, bahkan $65 \%$ staff merasa khawatir bahwa pekerjaan mereka pada akhirnya akan digantikan oleh aplikasi atau mesin. Meskipun semua karyawan merasa yakin bahwa proses ini akan membuat perusahaan menjadi lebih unggul dibandingkan dengan pesaing, beberapa karyawan $(41 \%)$ merasa tidak nyaman dengan banyak perubahan yang terjadi. Sebagian besar karyawan merasa tertekan, karena kecemasan timbul dari tuntutan pekerjaan eksternal dan internal yang semakin meningkat (56\%), tetapi loyalitas karyawan masih baik, karena hampir sebagai besar (81\%) tidak berniat mengundurkan diri dari pekerjaan, sebagian karena mereka merasa masih memiliki harapan karir yang baik (68\%).

Dari hasil survei di atas, dapat disimpulkan bahwa ada kecemasan pekerja yang timbul seiring dengan berjalannya proses perubahan. Munculnya niat untuk mengundurkan diri dari pekerjaan (19.51 \%) merupakan indikator ketidakpuasan kerja. Tekanan yang dialami oleh 
karyawan dalam lingkungan kerja yang mengutamakan pelayanan nasabah, merupakan hal yang harus disikapi dengan baik oleh pihak managemen, untuk mempertahankan level keterikatan karyawan pada perusahaan. Level keterikatan/engagement merupakan salah satu kunci keberhasilan perubahan yang terjadi. Resistensi dari karyawan selama proses berlangsung akan memberatkan keseluruhan implementasi, bahkan tidak mungkin akan berperan besar pada kegagalan program secara keseluruhan.

Stress sudah bukan merupakan isu kesehatan yang langka di abad ke 20. Stress merupakan problem yang menyangkut kesehatan fisik dan mental individu, dan menjadi concern perusahaan dan pemerintah karena tingginya financial damage. Stress dalam pekerjaan secara akademik dibahas dan diteliti pertama kali oleh Selye, ${ }^{13}$ pada tahun 1936, didefinisikan saat ini sebagai efek psikologis yang muncul akibat adanya tekanan yang dirasakan oleh seorang individu dalam pekerjaannya, dimana individu tersebut berusaha melawan tekanan tersebut. Stress kerja merupakan perasaan disfungsi personal pekerja sebagai akibat dari pengolahan persepsi kondisi yang terjadi di lingkungan kerja, dan reaksi psikologis dan fisikologis pekerja atas ancaman yang dirasakan pekerja di lingkungan kerjanya. ${ }^{14}$ Dalam takaran tertentu, jika ditanggapi dengan bijak, stress merupakan hal yang biasa dihadapi, dan dapat memunculkan motivasi positif untuk bekerja lebih keras untuk mencapai target dan ekspektasi. Stress kerja yang tidak dijaga dan dikelola dengan baik dapat menyebabkan tingginya absenteisme, turnover, penurunan produktivitas, dan peningkatan biaya kesehatan. ${ }^{15}$

Keberhasilan perusahaan untuk memantau dan mengelola stress kerja karyawan sangat penting dan berhubungan dengan usaha mempertahankan dan meningkatkan produktivitas perusahaan. ${ }^{16}$ Pada konteks lingkungan kerja yang sedang mengalami perubahan, banyak faktor yang menyebabkan stress pada pekerja, antara lain sebagai berikut: ketidakjelasan peran sehubungan dengan perubahan struktur organisasi, kewajiban mengikuti perkembangan teknologi yang cepat, perubahan birokrasi, policy dan prosedur. ${ }^{17}$ Persepsi risiko pekerja mengenai kemungkinan adanya pengurangan tenaga kerja dan menurunnya kesempatan karir, ditambah penurunan kepercayaan diri akibat berubahnya prosedur kerja yang sudah berjalan selama bertahun-tahun, perubahan kondisi lainnya juga memberikan kontribusi pada level stress pekerja ${ }^{18}$ dan seringkali membuat pekerja menjadi resistant terhadap perubahan, sehingga akhirnya akan melakukan tindakan yang menghambat jalannya perubahan itu sendiri. ${ }^{19}$ Pengurangan tenaga kerja adalah salah satu isu yang tidak bisa diabaikan pada era tranformasi digital, dan menjadi sumber stress utama

${ }^{13}$ Selye H. A syndrome produced by diverse nocuous agents. Nature vol 138, 1936, 32.

${ }^{14}$ Xu, Y. X., Mastura, S., \& Bakar, S. A., Impact of Work Experience, Interpersonal Relationship And Employee's Capability On Work Stress Of Industrial Bank's Employees In Zhengzhou, China. Inti Journal, $2019,2$.

${ }^{15}$ Osibanjo 0, et al. Workplace Stress: Implication for Organizational Performance in a Nigerian Public University, Journal of Vilnius Gediminas Technical, 2016, 262.

16 Landy, F J., Work in the 21st century, Binder ready version: An introduction to Industrial and Organizational Psychology. John Wiley \& Sons, 2016, 154.

17 Glambek, M, Anders S, Ståle E. Workplace bullying, the development of job insecurity and the role of laissez-faire leadership: a two-wave moderated mediation study. Journal of Work \& Stress 32 issue 3 2018, 302.

18 Van Dijk, R., \& Van Dick, R., Navigating organizational change: Change leaders, employee resistance and work-based identities. Journal of change Management, 9(2), 2009, 149.

${ }^{19}$ Teo, S. T., Pick, D., Xerri, M., \& Newton, C., Person-organization fit and public service motivation in the context of change. Public Management Review, 18(5), 2016, 741. 
bagi sebagian karyawan. Pada awal 2017 bank-bank di Uni Eropa telah menutup 9.100 cabang dan memberhentikan lebih dari 40 ribu karyawan, karena perubahan cara pelanggan melakukan transaksi. Dalam beberapa tahun ke depan, Indonesia diprediksi akan mengalami siklus yang sama, ketika mayoritas pelanggan mulai meninggalkan layanan perbankan konvensional dan proses digitalisasi sudah berjalan maksimal. Dari sisi eksternal, karyawan juga mungkin mencemaskan adanya kegagalan memenuhi ekspektasi nasabah yang semakin tinggi akan layanan perbankan dan kekhawatiran adanya tuntutan pihak ketiga akibat kesalahan proses. Persepsi risiko inilah yang kemudian menjadi sumber dari work stress, yang seringkali membuat pekerja menjadi resistant terhadap perubahan, sehingga akhirnya akan melakukan tindakan yang menghambat jalannya perubahan itu sendiri .

Pekerja sektor jasa yang mengalami stres jika tidak ditangani dengan benar akan menurunkan level engagement dan kinerjanya. ${ }^{20}$ Kegagalan untuk menyelesaikan tugas akan membuat pekerja lebih stres, terutama jika tugas tidak jelas, tumpang tindih, dan terdapat discrepancy antara, kondisi yang biasanya ditemukan di organisasi yang mengalami perubahan radikal. ${ }^{21}$

Dalam proses transformasi dan perubahan radikal yang dilakukan perusahaan, sangat penting bagi perusahaan untuk dapat menjaga level keterikatan karyawan (employee engagement). Karena karyawan dengan memiliki keterikatan yang kuat dengan perusahaan akan memberikan dukungan selama proses perubahan, bahkan menjadi agent of change yang dapat menularkan rasa positifivisme dan optimisme dikalangan karyawan. Karyawan yang memiliki keterikatan yang tinggi akan mendukung dan berpartisipasi aktif dalam perubahan budaya perusahaan menjadi lebih inovatif dan mampu menjaga keberlangsungan proses sejalan dengan strategi perusahaan. Pada akhirnya karyawan merupakan salah satu unsur penting dalam keberhasil perubahan yang terjadi pada proses transisi. Salah satu tujuan penulisan makalah ini adalah untuk melakukan deteksi dini stress karyawan yang kemungkinan akan meningkatkan risiko yang mungkin dihadapi perusahaan sehubungan dengan perubahan radikal yang terjadi selama proses transformasi. Dari hasil penelitian ditemukan adanya kecemasan karyawan mengenai berbagai kondisi yang timbul berkaitan dengan proses transformasi. Jika tingkat stress ini tidak dijaga, dikhawatirkan akan menurunkan kepuasan kerja dan keterikatan karyawan yang dapat mengancam kelancaran proses perubahan. Berdasarkan hasil survei tersebut di atas, penelitian lebih lanjut disarankan untuk membahas pengaruh stress kerja terhadap beberapa variabel sumber daya manusia yang mungkin terpengaruh selama perubahan radikal, antara lain adalah efikasi diri, kepuasan kerja, keterikatan karyawan dan kinerja karyawan. Hasil dari studi lanjutan ini dapat memberikan masukan yang berarti bagi proses transformasi digital di industri perbankan Indonesia, sehingga diharapkan dalam memberikan kontribusi maksimal pada keberhasilan keseluruhan proses.

Untuk memastikan tidak adanya hambatan untuk proses perubahan, perusahaan perlu memperhitungkan semua aspek dan kondisi yang mungkin dan akan terjadi. Salah satu aspek terpenting adalah bagaimana mengelola salah satu asset terbesar perusahaan, yaitu sumber daya manusia. Dalam kondisi perubahan yang radikal, akan muncul dampak terhadap kondisi

${ }^{20}$ Eldor, L., Public service sector: The compassionate workplace-The effect of compassion and stress on employee engagement, burnout, and performance. Journal of Public Administration Research and Theory, 28(1), 2017, 91.

${ }^{21}$ Norbert K. Semmer, Nicola Jacobshagen, Laurenz L. Meier, Achim Elfering, Terry A. Beehr, Wolfgang Kalin \& Franziska Tschan, Illegitimate tasks as a source of work stress, Work \& Stress: An International Journal of Work, Health \& Organisations, 29:1, 2015, 35.

Iqtishadia: Jurnal Ekonomi dan Perbankan Syariah

Vol. 7 No. 1 Juni 2020 
emosional dan well being karyawan.22 Adanya persepsi pekerja tentang kemungkinan dan risiko pengurangan tenaga kerja dan menurunnya peluang karir, ditambah penurunan tingkat kepecayaan diri, sebagai akibat dari perubahan prosedur, proses digitalisasi dan perubahan kondisi lain berpotensi menjadi sumber stress kerja. ${ }^{23}$ Kondisi ini sering membuat pekerja cenderung menolak perubahan, sehingga mereka pada akhirnya akan mengambil tindakan yang menghambat jalannya perubahan itu sendiri.

Perubahan radikal yang terjadi pada organisasi juga dapat menurunkan nilai efikasi diri karyawan. Efikasi diri atau self efficacy adalah pandangan pekerja terjadap kemampuannya menjalankan, mengorganisasi langkah-langkah yang dibutuhkan untuk mencapai tujuan atau targetnya. ${ }^{24}$ Efikasi diri diperlukan dalam proses transformasi karena termasuk syarat penting yang dibutuhkan seorang individu dalam menghadapi tantangan perubahan yang dapat mendorong peningkatan kinerjanya. ${ }^{25}$

Perubahan juga dapat menurunkan level kepuasan kerja karyawan. Kepuasan kerja merupakan aspek yang sangat penting bagi pekerja di industri jasa karena pekerja yang puas dengan pekerjaan mereka akan memberikan layanan yang baik kepada pelanggan mereka. ${ }^{26}$ Salah satu indikasi ketidakpuasan kerja adalah level intensi turnover yang tinggi. Menjaga level kepuasan karyawan, dan mengawal proses perubahan dengan gaya kepemimpinan yang tepat merupakan salah satu hal yang esensial, karena kepuasan kerja dan gaya kepemimpinan sangat terkait dengan produktivitas karyawan. ${ }^{27}$ Riyanto, ${ }^{28}$ juga menemukan hubungan yang kuat antara kepuasan kerja dan kinerja karyawan yang akan berpengaruh signifikan terhadap kinerja perusahaan. Aspek lain yang mungkin akan terdisrupsi adalah level employee engagement/keterikatan karyawan. Menjaga level engagement saat ini merupakan bagian dari strategi mempertahankan sustainibilitas perusahaan Pada perusahaan yang sedang menjalankan transformasi, harus diperhatikan kondisi level keterikatan karyawan, karena karyawan yang engaged yang akan memberikan benefit terbaik bagi perusahaan. Berdasarkan riset AON, level employee engagement negara-negara Asia, ditengah kondisi makroekonomi yang kian sulit dan perubahan akibat disrupsi digital, masih lebih tinggi dibandingkan belahan dunia lain, ${ }^{29}$ ditentukan oleh kebijakan perusahan yang tepat, loyalitas karyawan yang cukup baik dan tata nilai organisasi yang mendukung

\footnotetext{
${ }^{22}$ Anderson D, Anderson LA, Beyond change management: How to achieve breakthrough results through concious change leadership, John \& Wiley Publication, 2010.

${ }^{23} \mathrm{Niu}, \mathrm{H}$, Investigating effect of self efficacy on food service industry employees career commitment, International Journal of Hospitality Management, 29; 2010, 748.

${ }^{24}$ Wang, H. J., Demerouti, E., \& Le Blanc, P., Transformational leadership, adaptability, and job crafting: The moderating role of organizational identification. Journal of Vocational Behavior, 100, 2017, 193.

25 Rapp, A., Baker, T. L., Bachrach, D. G., Ogilvie, J., \& Beitelspacher, L. S., Perceived customer showrooming behavior and the effect on retail salesperson self-efficacy and performance. Journal of Retailing, 91(2), 2015, 361.

${ }^{26}$ George E, Job Related stress and job satisfaction: a comparative study among bank employees Journal of Management Development Vol. 34 No. 3, 2015, 321.

${ }^{27}$ Maida, M. T., Riyanto, S., \& Ali, H. Effect of Job Satisfaction and Leadership Style towards Employee Productivity at PT. Asuransi Umum Bumiputera Muda 1967. Saudi Journal of Business and Management Studies (SJBMS), 2017, 167.

${ }^{28}$ Riyanto, S. Effect of Motivation and Job Satisfaction on the Performance of Teachers in Mentari School Bintaro (MSB). Journal of Target, 2017, 90.

${ }^{29}$ Hickey, S, Morris M, Hire to Rapidly Accelerate Employee Engagement: What's the Formula, Aonhewitt Publication available in https://apac.aonhewitt.com/home/insights-at-work/hire-to-rapidlyaccelerate-employee-engagement, 2018.

62
}

Iqtishadia: Jurnal Ekonomi dan Perbankan Syariah

Vol. 7 No.1 Juni 2020 


\section{KESIMPULAN}

Penelitian ini merupakan penelitian awal terhadap dampak stress kerja dalam lingkungan yang mengalami perubahan yang radikal. Hasil penelitian dapat digunakan sebagai pra survey untuk penelitian lanjutan. Keterbatasan makalah ini, adalah bahwa survei dilakukan di cabang bank swasta yang dipilih untuk menjadi percontohan cabang transformasi digital. Data pengambilan sampel idealnya diambil dari beberapa cabang dari beberapa jenis bank yang beroperasi di Indonesia (bank pemerintah, bank swasta, bank syariah dan bank daerah), dengan populasi sampel yang lebih besar. Menimbang bahwa ada masih sedikitnya studi yang membahas masalah transformasi digital dalam bisnis perbankan di negara-negara berkembang, studi lebih lanjut sangat disarankan

\section{DAFTAR PUSTAKA}

Anderson D, Anderson LA, Beyond change management: How to achieve breakthrough results through concious change leadership, John \& Wiley Publication, 2010

Andrews J, Brown J, People Strategy for the Digital Age : A New take on talent, PWC Global Report, available on https://www.pwc.com/gx/en/services/peopleorganisation/publications/people-strategy.html, 2015

Berman, S. J., Digital transformation: opportunities to create new business models. Journal of Strategy \& Leadership, 40(2), 16-24, 2012

CapGemini, World Retail Banking Report. Available http://www.capgemini.com, 2016

Eldor, L., (2017), Public service sector: The compassionate workplace-The effect of compassion and stress on employee engagement, burnout, and performance. Journal of Public Administration Research and Theory, 28(1), 86-103.

George E, Job related stress and job satisfaction: a comparative study among bank employees Journal of Management Development Vol. 34 No. 3, 2015 pp. 316-329, 2015

Glambek, M, Anders S, Ståle E. Workplace bullying, the development of job insecurity and the role of laissez-faire leadership: a two-wave moderated mediation study. Work \& Stress 32.3 (2018): 297-312, 2018

Hickey, S, Morris M, Hire to Rapidly Accelerate Employee Engagement : What's the Formula, Aonhewitt Publication available in https://apac.aonhewitt.com/home/insights-atwork/hire-to-rapidly-accelerate-employee-engagement, 2018

Hornstein, H. A., The integration of project management and organizational change management is now a necessity. International Journal of Project Management, 33(2), 291-298, 2015

Jahn, C. G., \& Kruse, P. 'Partly Reversed Measures': Critically Assessing the Management of Resistance Within Radical Changes-Accompanying Banking Employees on Their Identity Journey During Digital Transformation, Lund University Lib, 2019

Keane, M. A., Undercurrents of the Changes to Work that Automation Brings. University of Twente, 2018

Kominfo, Press Release No 53/HMKOMINFO/02/2018, available at https://kominfo.go.id/index.php/content/detail/12640/siaran-pers-no-

53hmkominfo022018-tentang-jumlah-pengguna-internet-2017-meningkat-kominfoterus-lakukan-percepatan-pembangunan-broadband/0/siaran pers, 2018

Landy, F J., Work in the 21st century, Binder ready version: An introduction to Industrial and Organizational Psychology. John Wiley \& Sons, 2016.

Liu, D., Chen, S., \& Chou, T. Resource fit in digital transformation. Management Decision, 49(10), 1728-1742, 2011 
Maida, M. T., Riyanto, S., \& Ali, H. Effect of Job Satisfaction and Leadership Style towards Employee Productivity at PT. Asuransi Umum Bumiputera Muda 1967. Saudi Journal of Business and Management Studies (SJBMS). www. scholarsmepub. com/sjbms, ISSN, 2415-6563, 2017

Nguyen T, Phuong Dang T, Digital Banking in Vietnam Current Situation and Recommendations, International Journal of Innovation and Research in Educational Sciences Volume 5, Issue 4, ISSN (Online) : 2349-5219, 2018

$\mathrm{Niu}, \mathrm{H}$, Investigating effect of self efficacy on food service industry employees career commitment, International Journal of Hospitality Management, 29; 743-750 , 2010

Norbert K. Semmer, Nicola Jacobshagen, Laurenz L. Meier, Achim Elfering, Terry A. Beehr, Wolfgang Kälin \& Franziska Tschan, Illegitimate tasks as a source of work stress, Work \& Stress: An International Journal of Work, Health \& Organisations, 29:1, 32-56, 2015

Omarini, Anna. The digital transformation in banking and the role of FinTechs in the new financial intermediation scenario. International Journal of Finance, Economics and Trade (2017): 1-6. 2017

Osibanjo 0, et al. Workplace Stress : Implication for Organizational Performance in a Nigerian Public University, Journal of Vilnius Gediminas Technical 2016ed, 2016

Rapp, A., Baker, T. L., Bachrach, D. G., Ogilvie, J., \& Beitelspacher, L. S., Perceived customer showrooming behavior and the effect on retail salesperson self-efficacy and performance. Journal of Retailing, 91(2), 358-369, 2015

Riyanto, S. Effect of Motivation and Job Satisfaction on the Performance of Teachers in Mentari School Bintaro (MSB). Journal of Target, 83-91, 2017

Richard M, Kala Bisnis Percetakan Uang Peruri Digerogoti Uang Digital, Artikel Bisnis.com, Nov 2019 Edition, 2019

Selye H. A syndrome produced by diverse nocuous agents. Nature 138(3479, July 4):32, 1936

Sitanggang L, Bankir Akui Bisnis Kartu Kredit terdisrupsi Uang Elektronik, News Data Financial Tool, Artikel Kontan Juni 2019 Edition, 2019

Teo, S. T., Pick, D., Xerri, M., \& Newton, C., Person-organization fit and public service motivation in the context of change. Public Management Review, 18(5), 740-762, 2016

Van Dijk, R., \& Van Dick, R., Navigating organizational change: Change leaders, employee resistance and work-based identities. Journal of change Management, 9(2), 143-163, 2009

Wang, H. J., Demerouti, E., \& Le Blanc, P., Transformational leadership, adaptability, and job crafting: The moderating role of organizational identification. Journal of Vocational Behavior, 100, 185-195, 2017

Winasis S, et al, Digital Transformation in Indonesian Banking Industry : Impact on Employee Engagement, International Journal of Innovation, Creativity and Change, Volume 12 Issue 4,2020

$\mathrm{Xu}, \mathrm{Y} . \mathrm{X} ., \mathrm{Mastura}, \mathrm{S} .$, \& Bakar, S. A., Impact Of Work Experience, Interpersonal Relationship And Employee's Capability On Work Stress Of Industrial Bank's Employees In Zhengzhou, China. INTI JOURNAL, 2019(46), 2019 